\title{
Surface Treatment of Zirconia Implant, Its Surface Roughness and Its Effect on Osseointegration - A Review
}

\author{
Roseline Meshramkar $^{* 1}$, Praveen Shetty ${ }^{2}$, Aishwarya Nayak ${ }^{3}$, Gouri V. Anehosur ${ }^{4}$ \\ ${ }^{1}$ Professor and Hod, Department of Prosthodontics, SDM College of Dental Sciences and Hospital, \\ Dharwad, Karnataka-580009 \\ ${ }^{2}$ Professor, Department of Biochemistry, SDM College of Medical Sciences, Dharwad \\ ${ }^{3}$ Assistant Professor, Department of Prosthodontics, SDM College of Dental Sciences, Dharwad \\ ${ }^{4}$ Associate Professor, Department of Prosthodontics, SDM College of Dental Sciences, Dharwad \\ *Corresponding Author: Dr. Roseline Meshramkar; roselinemeshramkar@ yahoo.co.in
}

Received 08 May 2019;

Accepted 21 May 2019;

Published 31 May 2019

\begin{abstract}
Zirconia implant treatment is currently overriding other prosthetic solutions in replacing anterior teeth in esthetic zone. Surface topography of biomaterial has major impact on osseointegration. Various chemical and physical modifications have been developed to improve osseointegration. This review focuses on different surface treatment of zirconia implant. Surface roughness and its effect on osseointegration.
\end{abstract}

Keywords: Dental Implant, zirconia, Surface treatment, Osseointegration, Surface topography.

\section{Introduction}

Implant treatment is currently overriding other prosthetic solutions especially in case of replacing anterior teeth in esthetic zone. The tremendous increase in patients demands and expectations from dental treatment is progressively, growing which has made clinicians interested in the osseointegration and survival of implant. $^{[1,2]}$ The main reasons for the clinical use of zirconia implants are their biocompatiblity, good chemical and dimensional stability, high flexural strength (900 to $1200 \mathrm{MPa}$ ), adequate hardness (1200 Vickers) and Weibull modulus (10 to 12), toothlike color, low thermal conductivity, machinability, comparable osseointegration to titanium implants, reduced plaque affinity and low corrosion potential. ${ }^{[3-8]}$ As the surface topography of a biomaterial has a major impact on osseointegration, various chemical and physical surface modifications have been developed to improve osseous healing of implants. Increased surface roughness of dental implants resulted in greater bone apposition 4 and reduced healing time 5. Surface modification of zirconia can be achieved by altering the topography and altering the surface chemistry. Different approaches are being used in an effort to improve surface properties of zirconia. For this reason, research has focused on improving the surface bioactivity of zirconia-based materials in order to enhance the bone-to-implant contact, as well as the speed of bone formation, to reach optimal standards. Selective infiltration etching, Low pressure particle abrasion,
Fusion sputtering, Laser irradiation, Air bone particle abrasion, Acid etching with hydrochloric and hydrofluoric acid, Plasma spraying, Aggregation of bioactive materials such as hydroxyapatite, Ultraviolet radiation for photo functionalization, Nanotechnology modified zirconia. ${ }^{[10-19]}$

The aim of this review is to investigate the effect of different surface treatment on the osteoblastic activity of zirconia.

\section{Discussion}

Zirconia poses a challenge for surface modifications by surface treatments. Various novels surface treatments have been advocated to improve osseiointegration of zirconia implants. It is well known that the surface characteristics of implants and their alterations play an important role in the establishment of osseointegration. ${ }^{[4-7]}$ Surface roughening procedures that are used for titanium may influence zirconia surface properties negatively. ${ }^{[3-6]}$ In 2009 Hisbergus et al ${ }^{[20]}$ demonstrated that acid etching of zirconia do not provide surface roughness. In a study done by Gahlert et al, ${ }^{[4]} 2007$ reported that osseintegration capacity of machined zirconia surface can be substantially increased after modification by $\mathrm{Al}_{2} \mathrm{O}_{3}$ sand blasting. However sand blasting may have a negative effect on the microstructure of zirconia leading to - initial transformation of zirconia surface from the tetragonal to the monoclinic phase and thereby reducing the resistance to low thermal degradation Kohal 
et al ${ }^{[5]} 2008$, Andreotelli et al ${ }^{[8]} 2009$ in their report suggested that low thermal degradation will weaker the surface stability of zirconia materials thus possibly leading to promotion failure of sand blasted implant. Selective infiltration etching technique [SIE] employs the coating of zirconia with special infiltration glass and heated above its glass transiton temperature. After cooling to room temperature the glass is dissolved in acidic bath, exposing the newly created nano scale intergrain surface porosities. In this surface treatment is selective as it involves only the surface grains and the architecture and distribution of in 2011 Aboushelib et al ${ }^{[21]}$ found SIE effective way of enhancing the osseointegration. The major component for the clinical success of oral implants is the establishment of an immediate contact between the implant and the adjoining bone. Cap is regarded as a bioactive material having a direct bonding capacity to sourrounding bone. Thomas et al 1987, ${ }^{[22]}$ Geesink et al, ${ }^{[23]}$ Kim et al, ${ }^{[24]} 2004$ have reported that cap implant coatings accelerate early bone formation and osseointegration. Cap nanotechnology implant coatings have shown to accelerate local bone formation by research conducted by Webster et $\mathrm{al}^{[25]}$ in 2000 and Yang et $\mathrm{al}^{[26]}$ in 2001. In a study done by Jaebow lee 27, 2009 where they evaluated nano technology modified zirconia oral implant in rabbits and reported that cap nanotechnology does not enhance osteo conductivity. Laser modifications have been used to micro structure zirconia surface. A study done by Stubinger 28 in 2008 reported CO2 laser caused undesirable effects on the surface such as Micro cracks pits and melting of the material. Liu et $\mathrm{al}^{[27]}$ in 2005 demonstrated that zirconia posess photo catalytic activity when exposed to UV light by removal of hydrophobic layer of hydrocarbons from the surface of the material. Att et $\mathrm{al}^{[19]}$ in 2009 observed that, UV light treatment transformed the zirconia surface from hydrophobic to hydrophilic status. It has been particularly challenging to enhance the osteo conductive capacity of zirconia by its surface topographical modification.

\section{Conclusion}

There are many challenges concerning osteo conductive capacity of zirconia dental implants. Also surface roughening procedure that are used for titanium may influence zirconia surface properties negatively. Thus to enhance clinical outcomes, there is a need for specific surface modification techniques. The present review provides insight into bioactive zirconia implants.

\section{References}

[1] Zembic A, Sailer I, Jung RE \& Hammerle, CH Randomized controlled clinical trial of customized zirconia and titanium implant abutments for single-tooth implants in canine and posterior regions: 3-year results. Clinical Oral Implants Research. 2009; 20:802-8.

[2] Meijer HJA, Stellingsma K, Meijndert L, Raghoebar GM. A new index for rating aesthetics of implantsupported single crowns and adjacent soft tissues - the Implant Crown Aesthetic Index. Ein neuer Index zur Wertung der Aesthetik von implantatgetragenen Einzelkronen und der angrenzenden Weichgewebe - der Implantat Kronen Aesthetik Index. Clinical Oral Implants Research. 2005; 16(6):645-9.

[3] Sennerby L, Dasmah A, Larsson B, Iverhed M. Bone tissue responses to surface-modified zirconia implants: A histomorphometric and removal torque study in the rabbit. Clin Implant Dent Relat Res 2005;7:13-20.
[4] Gahlert M, Gudeus T, Eichhorn S, Steinhauser E, Kniha $\mathrm{H}$, Erhardt W. Biomechanical and histomorphometric comparison between zirconia implants with varying surface textures and a titanium implant in the maxilla of miniature pigs. Clin Oral Implants Res 2007;18:662-8.

[5] Kohal RJ, Wolkewitz M, Hinze M, Han JS, Bächle M, Butz F. Biomechanical and histological behavior of zirconia implants: an experiment in the rat. Clin Oral Implants Res 2009;20:333-9.

[6] Piconi C, Maccauro G. Zirconia as a ceramic biomaterial. Biomaterials 1999;20:1-25.

[7] Gahlert M, Burtscher D, Grunert I, Kniha H, Steinhauser E. Failure analysis of fractured dental zirconia implants. Clin Oral Implants 2012;23:287-93.

[8] Andreiotelli M, Wenz HJ, Kohal RJ. Are ceramic implants a viable alternative to titanium implants? A systematic literature review. Clin Oral Implants Res 2009;20:32-47.

[9] Triplett RG, Frohberg U, Sykaras N, Woody RD: Implant materials, design, and surface topographies: their influence on osseointegration of dental implants. J Long Term Eff Med Implants 2003, 13:485-501.

[10] Buser D, Broggini N, Wieland M, Schenk RK, Denzer AJ, Cochran DL, Hoffmann B, Lussi A, Steinemann SG: Enhanced bone apposition to a chemically modified SLA titanium surface. J Dent Res 2004, 83:529-33.

[11] Cochran DL, Buser D, ten Bruggenkate CM, Weingart D, Taylor TM, Bernard JP, Peters F, Simpson JP: The use of reduced healing times on ITI implants with a sandblasted and acid-etched (SLA) surface: early results from clinical trials on ITI SLA implants. Clin Oral Implants Res 2002, 13:144-53.

[12] Sennerby L, Dasmah A, Larsson B, Iverhed M: Bone tissue responses to surface-modified zirconia implants: A histomorphometric and removal torque study in the rabbit. Clin Implant Dent Relat Res 2005, 7(Suppl 1):S13-20.

[13] Bachle M, Butz F, Hubner U, Bakalinis E, Kohal RJ: Behavior of CAL72 osteoblast-like cells cultured on zirconia ceramics with different surface topographies. Clin Oral Implants Res 2007, 18:53-9.

[14] Gahlert M, Gudehus T, Eichhorn S, Steinhauser E, Kniha $\mathrm{H}$, Erhardt W: Biomechanical and histomorphometric comparison between zirconia implants with varying surface textures and a titanium implant in the maxilla of miniature pigs. Clin Oral Implants Res 2007, 18:662-8.

[15] Li J, Fartash B, Hammarström L, Hermansson L: Effect of macrotexture produced by laser beam machining on the retention of ceramics implant in bone in vivo. Mater in Medicine 1994, 5:760-763.

[16] Gahlert M, Gudehus T, Eichhorn S, Steinhauser E, Kniha $\mathrm{H}$, Erhardt W. Biomechanical and histomorphometric comparison between zirconia implants with varying surface textures and a titanium implant in the maxilla of miniature pigs. Clin Oral Implants Res. 2007;18:662668.

[17] Rocchietta I, Fontana F, Addis A, Schupbach P, Simion M. Surface-modified zirconia implants: tissue response in rabbits. Clin Implant Dent Relat Res. 2009;20:844850 .

[18] Langhoff JD, Voelter K, Scharnweber D, et al. Comparison of chemically and pharmaceutically modified titanium and zirconia implant surfaces in 
dentistry: a study in sheep. Int J Oral Maxillofac Surg. 2008;37:1125-1132.

[19] Att W, Takeuchi M, Suzuki T, Kubo K, Anpo M, Ogawa T. Enhanced osteoblast function on ultraviolet lighttreated zirconia. Biomaterials. 2009;30:1273-1280.

[20] Hisbergues M, Vendeville S, Vendeville P. (2009) Zirconia: Established facts and perspectives for a biomaterial in dental implantology. J Biomed Mater Res B Appl Biomater 88: 519-529

[21] Aboushelib M, Salem N, Abotaleb A, Abd El Moniem N. (2011) Influence of surface nano-roughness on osseointegration of zirconia implants in rabbit femur heads using selective infiltration etching technique. J Oral Implantology.2013;39(5):583-590.

[22] Thomas, K. A., Kay, J. F., Cook, S. D. \& Jarcho, M. (1987) The effect of surface macro texture and hydroxyapatite coating on the mechanical strengths and histologic profiles of titanium implant materials. Journal of Biomedical Material Research 21, 1395-1414.

[23] Geesink, R. G. T., Groot, K. D. \& Klein, C. P. A. T. (1988) Bonding of bone to apatite-coated implants.The Journal of Bone and Joint Surgery. British Volume 70-B, $17-22$.
[24] Kim HW, Kong YM, Bae CJ, Noh YJ, Kim HE. (2004) Sol-gel derived fluorhydroxyapatite biocoatings on zirconia substrate. Biomaterials 25: 2919-2926.

[25] Webster, T. J., Ergun, C., Doremus, R. H., Siegel, R. W. $\&$ Bizios, R. (2000) Enhanced functions of osteoblasts on nanophase ceramics. Biomaterials 21, 1803-1810.

[26] Joint Surgery. British Volume 70-B, 17-22.

[27] Yang, C. (2001) The effect of calcium phosphate implant coating on steoconduction. Oral Surgery, Oral Medicine, Oral Pathology, Oral Radiology, and Endodontics 92, 606-609.

[28] Jaebum Lee, Janet H. Sieweke, Nancy A. Rodriguez , Peter Schüpbach, Håkan Lindström, Cristiano Susin, Ulf M. E. Wikesjö Evaluation of nano-technology-modified zirconia oral implants: a study in rabbits. J Clin Periodontol 2009; 36: $610-617$.

[29] Stubinger S, Homann F, Etter C, Miskiewicz M, Wieland M, Sader R. (2008) Effect of Er:YAG, CO(2) and diode laser irradiation on surface properties of zirconia endosseous dental implants. Lasers Surg Med 40: 223 228.

[30] Liu Z, Amiridis MD, Chen Y. (2005) Characterization of $\mathrm{CuO}$ supported on tetragonal $\mathrm{ZrO} 2$ catalysts for $\mathrm{N} 2 \mathrm{O}$ decomposition to N2. J Phys Chem B 109: 1251-1255. 